\title{
Fitting the Stocking Rate with Pastoral Resources to Manage and Preserve Mediterranean Forestlands: A Case Study
}

\author{
Elisa Bianchetto ${ }^{1}$, Ivan Buscemi ${ }^{2}$, Piermaria Corona ${ }^{3}$, Giovanni Giardina ${ }^{2}$, \\ Tommaso La Mantia ${ }^{2, *}$ and Salvatore Pasta ${ }^{4}$
}

1 Consiglio per la ricerca in agricoltura e l'analisi dell'economia agraria-Agrobiology and Pedology Research Centre (CRA-ABP), Piazza Massimo d'Azeglio 30, 50121 Firenze, Italy;

E-Mail: elisa.bianchetto@entecra.it

2 Agricultural and Forest Sciences Department, University of Palermo, Viale delle Scienze, Ed.4, Ingr. H, 90128 Palermo, Italy; E-Mails: ivan.buscemi@gmail.com (I.B.); giardinagiovanni@libero.it (G.G.)

3 Consiglio per la ricerca in agricoltura e l'analisi dell'economia agraria-Forestry Research Centre (CRA-SEL), viale Santa Margherita 80, 52100 Arezzo, Italy;

E-Mail: piermaria.corona@entecra.it

4 Institute of Biosciences and BioResources, National Council of Research (IBBR-CNR), Unit of Palermo, Corso Calatafimi n 414, 90129 Palermo, Italy; E-Mail: salvatore.pasta@ibbr.cnr.it

* Author to whom correspondence should be addressed; E-Mail: tommaso.lamantia@unipa.it; Tel.: +39-091-2386-1240.

Academic Editor: Marc A. Rosen

Received: 25 March 2015 / Accepted: 29 May 2015 / Published: 4 June 2015

\begin{abstract}
Pasture practices have affected Mediterranean forest ecosystems for millennia, and they are still quite widespread in mountainous areas. Nevertheless, in the last decades, the stability of forest ecosystems has been jeopardized due to the abandonment of traditional agro-pastoral practices, so that the gradual reduction of open areas due to progressive succession processes has caused a high increase of grazing pressure by livestock and wild ungulates feeding on forest areas. This paper aims at showing a methodological approach for evaluating the effect of applying measures in order to improve the grazing value of grasslands and ecotonal patches and lower the grazing impact on native woodlands. A protected area in Sicily (Italy) is considered as a representative case study. The analysis of remotely sensed imagery and several field surveys enabled to identify and map six different land use units subject to grazing, i.e., (1) forests; (2) grasslands (pastures dominated by palatable herbs and grasses); (3) overgrazed grasslands (dominated
\end{abstract}


by poisonous and/or thorny herbs and forbs, not palatable); (4) encroached pastures; (5) roadside firebreaks (dominated by palatable herbs) with no shrubs; and (6) wooded/ encroached roadside firebreaks. Several data were collected through sample plots selected within each land use unit, in order to assess their pastoral value. These data have been used to define current and optimal animal stock rates aiming at addressing pasture management planning towards a sustainable use of forestland and shrubland.

Keywords: grazing; forest clearings; pasture types; forestry; biodiversity; secondary succession

\section{Introduction}

One of the most critical features to cope with for the management of Mediterranean shrubland and forests is represented by grazing pressure [1]. In fact, grazing is often carried out without planning, often inducing an excessive disturbance on the grazed ecosystems, both concerning the number of grazing animals and the length of the stocking period.

Easy to put into practice in those territories where wooded and open areas co-occur, forest grazing is a common practice in Mediterranean environments, enabling livestock to find either alternative forage sources during summer, when herbs and grasses are not available, or to have shelter during the hottest hours of the day. Woodland exploitation for feeding animals has always been a matter of conflict between breeders and forest managers. Livestock farming still is a major activity in some rural hilly and mountain areas, especially with regards to extensive local quality productions, based on sustainable management. Any attempt to reduce the stocking rate still causes serious discontent among cattle farmers.

On the other hand, forest re-colonization processes due to the abandonment of agricultural activities in marginal areas are being experienced largely in northern Mediterranean countries. Colonization speed mostly depends upon local environmental conditions and disturbance regimes [2,3]: distinctively, in Italy, faster processes were reported in the Alps in comparison with the central-southern Apennines where slower succession rates have been recorded [4-6].

Nonetheless, during the last few years, both demand for high quality agricultural products and an increase in tourism have led to a significant recovery of farming activities in selected areas, thus inducing a slowdown in their recolonization by the forest. From this perspective, the spreading of multiple systems - such as silvopastoral, agro-forestry, agro-forestry-pastoral, and other forms related to local environmental, social, and historical characteristics - might again play a relevant role for the local bio-economy, even as an integrated approach to improve biodiversity conservation [7]. On the other hand, the end of transhumance practices and the seasonal short-distance movements from forests to arable lands, and vice-versa [8,9], caused a sensitive increase of grazing pressure on rather small surface areas and, in turn, a decrease of plant species richness [10,11]. Livestock grazing impact may even be exacerbated by the co-occurrence of wild ungulates, such as deers and wild boars. Finally, the presence of non-fodder species, as well as the process of secondary succession on forest clearings may also reduce the extent of grassland within or near the woody areas. Actually, under Mediterranean conditions, grazing animals often exploit shrubs as a valuable source for supplementary forage and, 
when allowed by forest regulations, the use of both forest undergrowth and evergreen maquis is commonly practiced.

Under such a rather contradictory framework, the assessment of the forage supply within a protected area in Sicily (Italy), historically devoted to livestock grazing, was here taken into consideration in order to evaluate how local vegetation types might be modified in the case of different management interventions. Forage supply from roadsides used as firebreaks was also considered, given that, if properly managed, roadsides explotation may lower the grazing pressure on forests.

Many studies concern the interactions between grazing and forests, especially in northern Europe [12]. In the Mediterranean area, specific deepening is mainly limited to rather isolated case studies (e.g., [13-18]), due to the very heterogeneous environmental and socioeconomic conditions along with different local traditional practices. More recently, some studies have been carried out on silvo-pastoral systems (see for example [19-21]).

The aim of this paper is to illustrate, as a commentary outline referred to the area of the Nature Reserve "Bosco della Ficuzza, Rocca Busambra, Bosco del Cappelliere e Gorgo del Drago", the methodological approach for estimating the current and potential stocking rate for each pasture type and the potential stocking rate issuing from the practices foreseen to improve pasture quality. Finally, the regulation of grazing pressure on wooded areas is discussed.

\section{Material and Methods}

\subsection{Study Area}

The research was carried out within the Nature Reserve "Bosco della Ficuzza, Rocca Busambra, Bosco del Cappelliere e Gorgo del Drago" (Figure 1), which hosts the most prominent woodland of Western Sicily. The 234 ha-wide study area considered here is located between $917 \mathrm{~m}$ and $950 \mathrm{~m}$ a.s.1, on soils derived from calcareous outcropping rocks. According to the classification of Rivas-Martínez [22], the study area is subject to thermo-Mediterranean subhumid bioclimate [23].

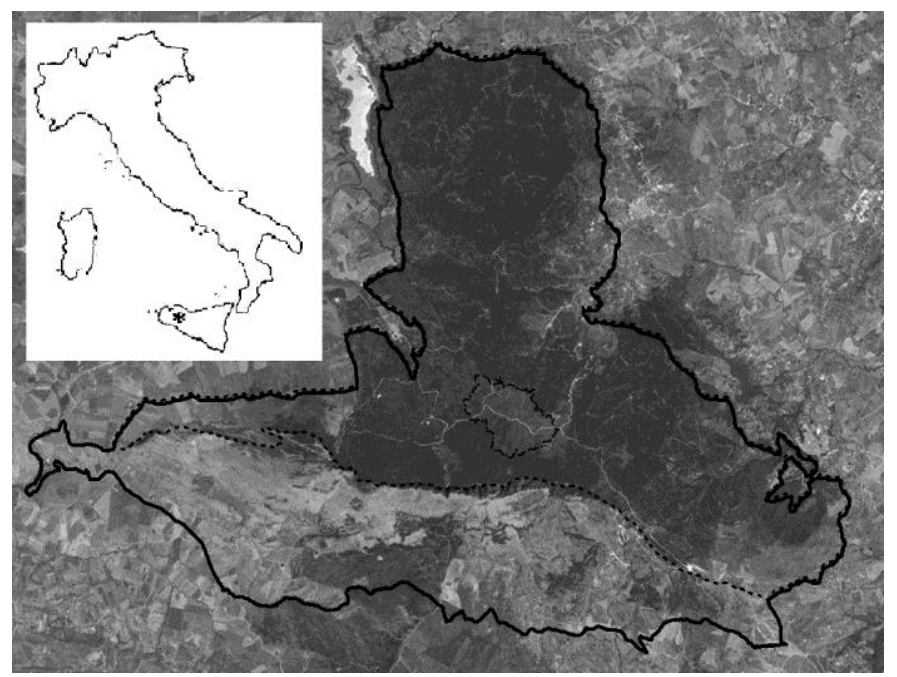

Figure 1. Boundary of the Nature Reserve "Bosco della Ficuzza, Rocca Busambra, Bosco del Cappelliere e Gorgo del Drago" (continuous line), study reference area (broken lines) and study area (dots and broken lines). 
The whole protected area hosts a very wide spectrum of forest communities, mainly dominated by evergreen (Quercus ilex L or Q. suber L.) and deciduous (Q. pubescens s.l. and Q. cerris s.l.) thermophilous oaks, with deciduous trees such as maples (Acer spp.), manna ashes (Fraxinus ornus L.) and Turkey oaks ( $Q$. cerris s.l.) playing a major role under cooler micro- and mesoclimatic conditions [23]. Forest degradation issues in a mosaic of shrubby communities were mainly dominated by Euphorbia spp., Fabaceae (Calicotome, Cytisus and Spartium) and thorny Rosaceae (Crataegus spp., Pyrus spp., Rosa spp., Rubus spp., etc.).

\subsection{Description of Grazing Pressure in the Nature Reserve}

Within the reserve five year-long grazing permissions are given by the Department for Rural and Territorial Development, whose grazing plan considers 45 different sectors, roughly based on the typology of plant cover and silvicultural issues. According to recent official data, the total surface of these sectors is 1090 ha, where 1630 adult cows are allowed to graze during seven months, i.e., between November and May. On the other side, the stocking rate is much greater than declared and that cattle feeds all year long, not only in the authorised but also in the unauthorised areas.

\subsection{Data Acquisition}

Six different pasture types were recognized in the study area: woodland pastures (dominated by woody forest species), overgrazed grasslands (dominated by poisonous and/or thorny herbs and forbs, not palatable), grasslands (dominated by palatable herbs and grasses), encroached pastures, roadside firebreaks (dominated by palatable herbs) with no shrubs; wooded/encroached roadside firebreaks. The six selected types of pastures are the most representative of local plant communities in the areas subject to grazing, where dedicated actions of pasture improvements are needed.

The heterogeneous patchwork of pasture types within the study area was mapped by open-source, very high-resolution remotely sensed images (ortho-corrected aerial photos in natural colors) coupled with extensive field surveys. Then, 18 100- $\mathrm{m}^{2}$-wide sampling plots were randomly selected, three for each pasture type. Within each plot, a phytosociological relevé [24] was carried out by surveying the species distribution within tree, shrub, and herb layers, and the recorded abundance and dominance were subsequently quantified according to Tüxen and Ellenberg [25]; additional information on aspect, slope, and stone-rock outcrop cover was collected, too.

\section{Data Processing}

The pastoral value (PV) of each plot was assessed according to Argenti et al. [26], so that three levels of increasing quality (poor, average, good) could be recognized. The method involves the calculation of the PV, which is a parameter that summarizes the estimated production potential of a pasture considering the quantitative and qualitative aspects [27]. A fodder value was associated with each plant species by the Specific Index (hereinafter indicated as SI), ranging from 0 to 5 as proposed by Daget and Poissonet [28]. SI integrates parameters such as (a) the plant nutritional value; (b) the forage quality (i.e., edibility, attractiveness, palatability, and digestibility); and (c) the plant tolerance-resilience to grazing. For each plant species, we adopted the SI values suggested by Roggero et al. [27] and 
Cavallero et al. [29]. For the species not listed by those authors, SI was assessed according to their taxonomic and phenological affinity with the listed species. The method is applied in Italy and in other countries where local SI lists are available [27,29]. The use of SI has two main biases: (1) it may vary along with different environmental conditions, so that a given species whose SI is considered 0 under optimal conditions (e.g., alpine pastures), where animals may feed on good quality pastures and have plenty of choice, may be grazed by the same animal where resource availability is scarcer (e.g., pastures of the semi-arid Mediterranean countries); (2) they do not take into account the eventual variation of plant's nutritional value during its different phenological phases.

Once the floristic composition of each sample plot and assigned SI to each considered plant species is recorded, the PV of each pasture type is assessed. PV is a non-dimensional index, ranging from 0 to 100 , describing the quality and quantity of available food within a given pastoral area [27]:

$$
P V=0.2 \times \sum S C P_{i} \times S I_{i}
$$

where $\mathrm{SCP}_{\mathrm{i}}$ is the Specific Contribution of Presence of the $i$-th species, that corresponds to the mean coverage value according to the scale of Tüxen and Ellenberg [25]; 0.2 is a multiplier coefficient which maintains PV values between 0 and 100 [30-32].

The vegetation type of each sampling plot, for which a given PV value is calculated, is considered as a representative of the corresponding pasture type, i.e., each pasture type can be associated to a PV that quantifies its forage potential ranked in terms of quality as proposed by Argenti et al. [26]: bad quality type $=\mathrm{PV} \leq 15$; medium quality type $=15<\mathrm{PV} \leq 25$; good quality type $=\mathrm{PV}>25$.

Once the PV has been estimated for a given pasture type, it is possible to assess the Potential Stocking Rate (PSR), defined as the potential amount of animals per hectare which can stay and feed in that pasture over a given period without causing the deterioration of the grazing resources. PSR is measured in livestock units (LU, sensu [33]) per hectare per year:

$$
\mathrm{PSR}=\mathrm{PV} \times \mathrm{K} \times \mathrm{VC}
$$

where $\mathrm{K}=$ conversion coefficient, ranging between 0.007 and $0.02 \mathrm{LU} \cdot \mathrm{ha}^{-1} \cdot \mathrm{year}^{-1}$, which depends on the abiotic context and the vegetation patterns of the studied pasture (in this paper, a 0.02 value, appropriate for hilly and mountain areas, has been adopted) [34]; VC = vulnerability coefficient, ranging between 1 (favorable sites) and 0.65 (hostile conditions), which depends on the local presence of limiting factors such as steep slopes, intense erosion, high percentage of outcropping stones-rocks, etc.

The geo-dataset available for the considered study area allowed to map local limiting factors in order to assign the appropriate VC value to each sample plot: distinctively, a 0.7 value was associated to sample plots under rugged site conditions and a 0.9 value to the others [35]. Maps provided accurate information on the extent of each pasture type and enabled to assess the PSR over the entire area where dynamic management of grazing resources has to be planned.

\section{Results}

The total number of plant species observed within each selected plot varies along with pasture types, showing an inverse proportionality with respect to their pastoral value (forests: 39; wooded/encroached roadside firebreaks: 37; overgrazed grasslands and encroached pastures: 32; roadside firebreaks with 
no trees: 31 ; grasslands: 20 ). The SI of all the species covering more than $5 \%$ of the surface of at least one sample plot are reported in Table 1.

Table 1. List and specific index (SI) of the plant species with a coverage higher than $5 \%$ on at least one sample plot. $\mathrm{F}=$ forests; $\mathrm{G}=$ grasslands; $\mathrm{OG}=$ overgrazed grasslands; $\mathrm{EP}=$ encroached pastures; $\mathrm{RFNT}=$ roadside firebreaks with no trees; $\mathrm{WERF}=$ wooded/encroached firebreaks, $*$ : present.

\begin{tabular}{|c|c|c|c|c|c|c|c|}
\hline \multirow[t]{2}{*}{ Species } & \multicolumn{7}{|c|}{ Pasture Type } \\
\hline & $\mathbf{F}$ & G & OG & EP & RFNT & WERF & Specific Index \\
\hline Achillea ligustica All. & & & & & & $*$ & 2 \\
\hline Elymus panormitanus (Parl.) Tzvelev & & & & $*$ & & & 1 \\
\hline Allium subhirsutum L. & $*$ & & & $*$ & & $*$ & 0 \\
\hline Anthoxanthum odoratum $\mathrm{L}$. & $*$ & & & & & & 2 \\
\hline Asphodelus ramosus L. & & & $*$ & $*$ & & $*$ & 1 \\
\hline Avena fatua $\mathrm{L}$. & & & $*$ & & & & 3 \\
\hline Calicotome infesta (C. Presl) Guss. & $*$ & & & & & & 0 \\
\hline Calystegia sepium (L.) R. Br. & & & & * & & & 1 \\
\hline Carthamus caeruleus L. & & & $*$ & $*$ & * & & 0 \\
\hline Centaurea solstitialis L. & & $*$ & & & $*$ & & 0 \\
\hline Cichorium intybus L. & & $*$ & $*$ & & & & 4 \\
\hline Crataegus orientalis M. Bieb. subsp. presliana K.I. Chr. & $*$ & & & & & & 2 \\
\hline Crataegus monogyna Jacq. & & & & $*$ & & & 2 \\
\hline Crepis leontodontoides All. & & & & & & $*$ & 3 \\
\hline Crepis vesicaria $\mathrm{L}$. & & & & & * & & 3 \\
\hline Cuscuta sp. & & & $*$ & & & & 1 \\
\hline Cynodon dactylon (L.) Pers. & & $*$ & & & & & 2 \\
\hline Cynosurus cristatus L. & $*$ & $*$ & $*$ & & $*$ & $*$ & 4 \\
\hline Dactylis hispanica Roth & $*$ & & $*$ & & & & 5 \\
\hline Daphne laureola L. & $*$ & & & & & & 0 \\
\hline Elaeoselinum asclepium (L.) Bertol. & & & $*$ & * & & & 0 \\
\hline Eryngium campestre $\mathrm{L}$. & & & & & $*$ & & 0 \\
\hline Eryngium triquetrum Vahl & & & $*$ & & * & & 1 \\
\hline Euphorbia ceraratocarpa Ten. & & & & $*$ & & & 0 \\
\hline Foeniculum vulgare Mill. subsp. piperitum (Ucria) Bég. & & & $*$ & & & & 2 \\
\hline Fraxinus angustifolia Vahl & & & & & & & 4 \\
\hline Hordeum bulbosum L. & & & & & & & 3 \\
\hline Hyoseris radiata $\mathrm{L}$. & & & & $*$ & & & 4 \\
\hline Hypochoeris radicata L. subsp. heterocarpa (Moris) Arcang. & & $*$ & & & * & & 3 \\
\hline Kundmannia sicula $\mathrm{L}$. & & & & $*$ & & $*$ & 0 \\
\hline Lolium perenne L. & & $*$ & & & & & 5 \\
\hline Lolium rigidum Gaudin & $*$ & & & & $*$ & & 5 \\
\hline Mentha pulegium L. & & * & & & & & 0 \\
\hline Oenanthe pimpinelloides L. & $*$ & $*$ & $*$ & $*$ & * & $*$ & 2 \\
\hline Phalaris coerulescens Desf. & & & $*$ & $*$ & $*$ & & 2 \\
\hline Helminthotheca echioides (L.) J. Holub & & & & & $*$ & & 3 \\
\hline Poa bulbosa L. & & $*$ & $*$ & & $*$ & $*$ & 3 \\
\hline
\end{tabular}


Table 1. Cont.

\begin{tabular}{|c|c|c|c|c|c|c|c|}
\hline \multirow[t]{2}{*}{ Species } & \multicolumn{7}{|c|}{ Pasture Type } \\
\hline & $\mathbf{F}$ & $\mathbf{G}$ & OG & $\mathbf{E P}$ & RFNT & WERF & Specific Index \\
\hline Poa trivialis L. subsp. sylvicola (Guss.) H. Lindb. f. & & & & & & $*$ & 4 \\
\hline Prunus spinosa $\mathrm{L}$. & $*$ & & $*$ & * & & & 0 \\
\hline Pulicaria odora (L.) Rchb. & $*$ & & & & & & 2 \\
\hline Pyrus spinosa Forssk. & & & & * & & & 0 \\
\hline Quercus virgiliana (Ten.) Ten. & $*$ & & & & & $*$ & 2 \\
\hline Ranunculus bulbosus L. & & & & & $*$ & $*$ & 0 \\
\hline Ranunculus muricatus L. & & * & & & & & 1 \\
\hline Rosa cfr. micrantha $\mathrm{Sm}$. & $*$ & & & $*$ & $*$ & & 0 \\
\hline Rubia peregrina $\mathrm{L}$. & & & & $*$ & & & 0 \\
\hline Rubus ulmifolius Schott & & & & $*$ & & & 0 \\
\hline Rumex conglomeratus Murray & & $*$ & & & & & 0 \\
\hline Ruscus aculeatus L. & $*$ & & & $*$ & & $*$ & 0 \\
\hline Scolymus grandiflorus L. & & & $*$ & & $*$ & & 0 \\
\hline Scorzonera villosaeformis (Fiori \& Bég.) Vierh. & & & & & & $*$ & 2 \\
\hline Sedum caespitosum (Cav.) DC. & & & & & * & & 0 \\
\hline Silene coeli-rosa $(\mathrm{L}$.$) Godron$ & & & $*$ & & * & & 0 \\
\hline Spartium junceum L. & & & & $*$ & & & 0 \\
\hline Trifolium angustifolium $\mathrm{L}$. & & & & & & $*$ & 2 \\
\hline Trifolium bivonae Guss. & $*$ & & & & & $*$ & 3 \\
\hline Trifolium campestre Schreber & $*$ & & $*$ & $*$ & & & 2 \\
\hline Trifolium incarnatum $\mathrm{L}$. & & & $*$ & & & $*$ & 4 \\
\hline Trifolium lappaceum $\mathrm{L}$. & & & $*$ & & * & & 2 \\
\hline Trifolium nigrescens Viv. & & $*$ & & & & & 5 \\
\hline Trifolium resupinatum $\mathrm{L}$. & & $*$ & & & & & 3 \\
\hline Urospermum dalechampii (L.) F.W. Schmidt & & & $*$ & & & & 2 \\
\hline Vicia benghalensis L. & & & $*$ & & & & 4 \\
\hline
\end{tabular}

Footnote: Explanation of the criteria adopted in order to evaluate SI. $0=$ avoided/poisonous/not palatable; $1-2$ : occasionally consumed/of low fodder value; 3: good fodder value; 4: very good fodder value; 5: excellent fodder value [36].

Table 2. Livestock Pastoral Value (PV) and Potential Stocking Rate (PSR) by pasture type in the study area (in brackets, the maximum and the minimum values).

\begin{tabular}{ccc}
\hline Pasture type & Average PV & $\begin{array}{c}\text { Average PSR } \\
\left(\mathbf{L U} \cdot \mathbf{h a}^{-\mathbf{1}} \cdot \mathbf{y e a r}^{-\mathbf{1}} \mathbf{)}\right.\end{array}$ \\
\hline Forests & $18.2(28.6-7.9)$ & $0.26(0.4-0.11)$ \\
Grasslands & $60.4(87.8-25.3)$ & $0.85(1.23-0.35)$ \\
Overgrazed grasslands & $23.5(28.7-18.3)$ & $0.33(0.4-0.26)$ \\
Encroached pastures & $14.7(33.7-1.8)$ & $0.21(0.47-0.03)$ \\
Roadside firebreaks with no trees & $27.9(46.9-8.55)$ & $0.39(0.66-0.12)$ \\
Wooded/encroached roadside firebreaks & $33.4(41.9-20)$ & $0.47(0.59-0.28)$ \\
\hline
\end{tabular}

Footnote: bad quality type $=\mathrm{PV} \leq 15$; medium quality type $=15<\mathrm{PV} \leq 25$; good quality type $=\mathrm{PV}>25[36]$. 
PV average of each considered pasture type is reported in Table 2. The highest PV values were recorded for grasslands dominated by palatable herbs and grasses such as Lolium perenne and Fabaceae (mainly Trifolium spp.) (Table 1); these pastures derive from abandoned cereal crop fields, which have turned into pastures during the second half of the XX century. Conversely, shrubland presents the lowest average PV, close to that of the forests.

PSR values show that the only pasture type suitable for sustainably hosting cattle is grassland, while less suitable is shrubland, whose average PSR is once again similar to that of the forests.

With regards to forests, their surface extent should remain unvaried. Low PV values of forest patches suggest their limited suitability for grazing, but this fact clashes with real practice, as within the study area, the woodlands are affected by animal impact throughout all the year. Allowing rational grazing within woods (Table 3) may induce some advantages in some peculiar cases (e.g., depression of coppice vigor during high forest conversions). However, a strict regulation of grazing surfaces and timing is mandatory.

Table 3. Post-intervention surfaces and calculated livestock load in the study area (see Table 1).

\begin{tabular}{cccc}
\hline Pasture type & $\begin{array}{c}\text { Surfac } \\
\text { (ha) }\end{array}$ & $\begin{array}{c}\text { Surface after } \\
\text { improvement } \\
\text { interventions (ha) }\end{array}$ & $\begin{array}{c}\text { Carrying capacity after pasture } \\
\text { improvement interventions } \\
\text { (LU· } \text { year }^{\mathbf{1}} \text { ) }\end{array}$ \\
\hline Forests & 6293.79 & 6293.8 & 1636 \\
Grasslands & 139.50 & $176.9^{*}$ & 150 \\
Overgrazed grasslands & 325.51 & $597.7^{* *}$ & 197 \\
Pastures colonized by shrubs & 465.02 & 155.4 & 32 \\
Roadside firebreaks with no trees & 200.58 & 200.6 & 37 \\
Wooded/encroached roadside firebreaks & 93.68 & 93.7 & 94 \\
Arable crops and fallows & 7 & - & - \\
\hline
\end{tabular}

* increase of surface derived from improvement interventions carried out on degraded pastures; ** increase of surface derived from mantle clearcutting.

\section{Discussion}

The adoption of the PV method helps to assess the numbers of animals sustainable for the study area and represents an effective tool in order to characterize grazed areas and to address pasture activity towards a more rational exploitation of local resources. The use of SI issued from standard international lists provides a rather rapid and effective tool in order to assess the PV in natural areas, which are managed through grazing animals $[37,38]$.

Only three species with $\mathrm{SI}=0$, a value typical of overgrazed pastures, have been recorded within grassland. This result underlines the potential of pasture restoration and management, even under the distinctive concern to be paid at a territorial planning level for the conservation and the valorization of traditional landscapes [39]: as a matter of fact, prescribed grazing could be a very effective tool to maintain high pastoral values and to avoid the spread of ubiquitous unpalatable species which could induce the lowering and homogenization of herbaceous cover. 
As far as woods are concerned, no intervention on the undergrowth is planned. Currently, livestock pressure within local woods is intense and widespread damage is evident, severely compromising tree regeneration rates [1]. On the other hand, our results show that woods play a scarce role as pasture resources due to the poor quality of the fodder they can provide. Thus, forest ecosystems should be managed more rationally by adopting two alternative solutions: (1) a first, and more drastic one, is to forbid grazing in woodlands; (2) the second is to allow livestock to enter in forests only during the summer period, when woody species may provide the only available fodder and shade against high temperatures. However, in this second case, grazing impact should be regulated and monitored in order to comply with the maximum stocking rate calculated through phytosociological relevés, thus avoiding a decrease of the PV of the forests.

The best way to enhance grasslands PV is to foster the improvement of overgrazed pastures by diminishing the stocking rate. No specific actions should be planned for grassland management, while a good reliable evaluation of potential stocking rate and a regular monitoring of the trend (in terms of species composition and coverage) of the plant communities within sample plots is necessary in order to eventually modulate livestock impact by shortening the grazing season.

Mechanized clearing of the shrub layer should be carried out as long as mantle species involved do not play an important ecological role (e.g., shelter for birds, ecological corridor, etc.), even if for a few years after such clearing interventions, the floristic composition and the PV of newly opened pastures will be similar to overgrazed pastures.

Under periodical mechanical mowing interventions, the pasture types "roadside firebreaks with no trees" and "wooded/encroached roadside firebreaks" may also be considered as pastures. The only advisable intervention in these areas appears to be continuing with regular mowing. Once again, the frequency of these interventions should depend on the results of regular monitoring activities in order to avoid the prevalence of few non-palatable plants typical to overgrazed grasslands.

Table 3 reports the potential of livestock increase in accordance with pasture improvement. Arable crops and fallows are also included here, since they can play an important role in hosting animals both in summer and in winter.

\section{Conclusions}

The improvement interventions here envisaged will affect overgrazed pastures, as $12 \%$ of pasture surface is expected to be converted into grasslands, as well as shrubland, $66 \%$ of which is expected to be transformed into pastures. During the first few years after interventions, the latter as well as roadside firebreaks will probably share the same features of the overgrazed pastures. On a sustainable management perspective, a mixture of vegetation succession stages should be preferred. Shrubland management will not undermine the overall ecological value of the study area: it would maintain high PV values typical of open areas, thus making grazing outside the forest more convenient. Furthermore, the proposed actions may provide better conditions for some animal communities: for instance, butterflies' richness is positively correlated with habitat patchiness and rapidly decreases along with the loss of clearings, so that regular shrub cutting and roadside mowing may induce positive effects on their population dynamics [40]. Finally, the management of pastoral resources in agreement with schemes like those proposed here may prove to be of high "social value" potential because they may 
change the attitude of local people with respect to shrubland and woodland use. The increase of grassland area and the improvement of grassland quality may encourage a more rational use of local pastures. On a planning level, pastures, considered in the strict sense of the term, can be exploited as multifunctional plant communities aimed at traditional forage production, biodiversity and landscape conservation, and recreational-touristic functions. Moreover, the interventions like those here envisaged need human resources throughout the year, with benefits for local employment. With less (or even without) social conflicts, policies such as grazing prohibition become useless, and both wildfires and illegal grazing might decrease. Future investigations are needed on whether mechanized interventions, such as mowing, may be actually effective in avoiding the seed dispersal of the species with low or no fodder value.

\section{Acknowledgments}

Special thanks to Giovanni Argenti for his many useful suggestions on pasture management policies, to Carlo Di Leo and Giuseppe Garfì for their support during data input and processing, and to Francesca Quatrini for the translation of a preliminary version of the manuscript. The authors are indebted to the Regional Department for Rural and Territorial Development and in particular to Giovanni Landini for the logistic support during field surveys. This work was financially supported by the MIUR-PRIN project "Climate change mitigation strategies in tree crops and forestry in Italy" (CARBOTREES).

\section{Author Contributions}

Salvatore Pasta carried out the phytosociological relevés; Ivan Buscemi carried out the remote-sensed interpretation and vegetation mapping; all the authors were involved in the experimental design planning, on land use classification and took part to SI evaluation; they also were involved in writing the paper and in revising it after referee comments and suggestions. All authors read and approved the final manuscript.

\section{Conflicts of Interest}

The authors declare no conflict of interest

\section{References}

1. La Mantia, T.; Pasta, S.; Giardina, G.; Marchetti, M. The effect of grazing in forests: The case study of Ficuzza (W Sicily). In Proceedings of the International Congress Silvopastoralism and Sustainable Management, Lugo, Spain, 18-24 April 2004.

2. Corona, P.; Calvani, P.; Mugnozza Scarascia, G.; Pompei, E. Modelling natural forest expansion on a landscape level by multinomial logistic regression. Plant Biosyst. 2008, 142, 509-517.

3. Targetti, S.; Staglianò, N.; Messeri, A.; Argenti, G. A state-and-transition approach to alpine grasslands under abandonment. iForest 2010, 3, 44-51. 
4. Biondi, E.; Andreucci, F. Dynamics of vegetation in the restoration of areas abandoned by agricultural and pastoral activities. In Responses of Forest Ecosystem to Environmental Changes; Teller, A., Mathy, P., Jeffers, J.N.R., Eds.; Elsevier Applied Sciences: Amsterdam, The Netherlands, 1991; pp. 945-947.

5. La Mantia, T.; Rühl, J.; Pasta, S.; Campisi, D.; Terrazzino, G. Structural analysis of woody species in Mediterranean old fields. Plant. Biosyst. 2008, 142, 462-471.

6. Alberti, G.; Leronni, V.; Piazzi, M.; Petrella, F.; Mairota, P.; Peressotti, A.; Piussi, P.; Valentini, R.; Gristina, L.; La Mantia, T.; et al. Impact of woody encroachment on soil organic carbon and nitrogen in abandoned agricultural lands along a rainfall gradient in Italy. Reg. Environ. Chang. 2011, 11, 917-924.

7. Dobson, A.P.; Bradshaw, A.D.; Baker, J.M. Hopes for the future: Restoration ecology and conservation biology. Science 1997, 277, 515-522.

8. Di Pasquale, G.; Garfì, G.; Migliozzi, A. Landscape dynamics in south-eastern Sicily in the last 150 years: The case of Iblei Mountains. In Recent Dynamics of Mediterranean Vegetation Landscape; Mazzoleni, S., di Pasquale, G., Mulligan, M., di Martino, P., Rego, F., Eds.; John Wiley \& Sons: Hoboken, NJ, USA, 2004; pp. 73-80.

9. Caballero, R. The territorial identity of large scale grazing systems in Europe. J. Earth Sci. Clim. Chang. 2012, 3, 1-26.

10. Bunce, R.H.G., Pérez-Soba, M., Jongman, A., Gómez Sal, A., Herzog, F., Austad, I., Eds. Transhumance and Biodiversity in European Mountains; Report from the EU-FP5 project Transhumount; IALE Publication Series No. 1; International Association for Landscape Ecology: Piestany, Slovakia, 2004; p. 321.

11. Blondel, J. Ups and downs in biological diversity across scales of time and space in the mediterranean: The role of humans. In Proceedings of the European IALE-Landscape Ecology in the Mediterranean: Inside and Outside Approach, Faro, Portugal, 29 March-2 April 2005; Bunce, R.G.H., Jongman, R.G.H., Eds.; IALE Pubblication Series; International Association for Landscape Ecology: Piestany, Slovakia, 2006; Volume 3, pp. 7-18.

12. Vera, F.W.M. Grazing Ecology and Forest History; CAB International: Wallingford, UK, 2000; p. 506.

13. Casasús, I.; Bernués, A.; Sanz, A.; Villalba, D.; Riedel, J.L.; Revilla, R. Vegetation dynamics in Mediterranean forest pastures as affected by beef cattle grazing. Agric. Ecosyst. Environ. 2007, $121,365-370$.

14. Gutman, M.; Henkin, Z.; Holzer, Z.; Noy-Meir, I.; Seligman, N.G. A case study of beef-cattle grazing in a Mediterranean-type woodland. Agroforest Syst. 2000, 48, 119-140.

15. Papachristou, T.G.; Papanastasis, V.P. Forage value of Mediterranean deciduous woody fodder species and its implication to management of silvo-pastoral systems for goats. Agroforest. Syst. 1994, 27, 269-282.

16. Papachristou, T.G.; Nastis, A.S. Influence of deciduous broadleaved woody species in goat nutrition during the dry season in northern Greece. Small Rumin. Res. 1996, 20, 15-22.

17. Papachristou, T.G. Foraging behaviour of goats and sheep on Mediterranean oak shrublands. Small Ruminant Res. 1997, 24, 85-93. 
18. Plieninger, T.; Pulido, F.J.; Schaich, H. Effects of land-use and landscape structure on holm oak recruitment and regeneration at farm level in Quercus ilex L. dehesas. J. Arid Environ. 2004, 57, 345-364.

19. Gakis, S.F.; Orfanoudakis, M.Z.; Papaioannou, A.G.; Mantzanas, K.T.; Papanastasis, V.P.; Alifragis, D.A.; Seilopoulos, D.G.; Kostakis, S.N. Long term evolution of tree growth, understorey vegetation and soil properties in a silvopastoral system of northern Greece. Ann. For. Res. 2014, 57, 247-265.

20. Klossas, G.; Kyriazopoulos, A.P.; Koukoura, Z. Post-planting treatments and shading effects in a Fraxinus angustifolia Vahl silvopastoral system. Ann. For. Res. 2013, 56, 179-186.

21. Sá-Sousa, P. The Portuguese montado: Conciliating ecological values with human demands within a dynamic agroforestry system. Ann. For. Sci. 2014, 71, 1-3.

22. Rivas-Martínez, S. 2008 Global bioclimatics (Clasificación bioclimática de la Tierra-versión 1 December 2008). Available online: http://www.globalbioclimatics.org (accessed on 26 September 2013).

23. Gianguzzi, L. Il paesaggio vegetale della Riserva Naturale Orientata Bosco della Ficuzza, Rocca Busambra, Bosco del Cappelliere, Gorgo del Drago. In The Vegetation Units of the Nature Reserve Bosco Della Ficuzza, Rocca Busambra, Bosco del Cappelliere, Gorgo del Drago; Collana Sicilia Foreste 22; Azienda Foreste Demaniali: Palermo, Italy, 2004; p. 159. (In Italian)

24. Braun-Blanquet, J. Plant Sociology; Mc Graw-Hill Book Company: New York, NY, USA; London, UK, 1932.

25. Tüxen, R.; Ellenberg, H. Der systematische und ökologische Gruppenwert. Ein Beitrag zur Begriffsbildung und Methodik der Pflanzensoziologie. Mitt. Flor.-Soz. Arbeitsgem. 1937, 3, 171-184. (In German)

26. Argenti, G.; Bianchetto, E.; Ferretti, F.; Staglianò, N. Proposta di un metodo semplificato di rilevamento pastorale nei piani di gestione forestale. Forest 2006, 3, 275-280. (In Italian)

27. Roggero, P.P.; Bagella, S.; Farina, R. Un archivio dati di Indici Specifici per la valutazione integrata del Valore Pastorale. Riv. Agron. 2002, 2, 149-156. (In Italian)

28. Daget, P.; Poissonet, T. Analyse phytologique des prairies. INRA Montp. Doc. 1969, 48, 1-66. (In French)

29. Cavallero, A.; Rivoira, G.; Talamucci, P. Pascoli. In Coltivazioni Erbacee. Foraggere e Tappeti Erbosi; Baldoni, R., e Giardini, L., Eds., Patron Editore: Bologna, Italy, 2002; pp. 239-294. (In Italian)

30. Argenti, G.; Lombardi, G. The pasture-type approach for mountain pasture description and management. Ital. J. Anim. Sci. 2012, 7, 293-299.

31. Tocco, C.; Probo, M.; Lonati, M.; Lombardi, G.; Negro, M.; Nervo, B.; Rolando, A.; Palestrini, C. Pastoral practices to reverse shrub encroachment of sub-Alpine grasslands: Dung beetles (Coleoptera, Scarabaeoidea) respond more quickly than vegetation. PLoS ONE 2013, 8, e83344.

32. Probo, M.; Massolo, A.; Lonati, M.; Bailey, D.W.; Gorlier, A.; Maurino, L.; Lombardi, G. Use of mineral mix supplements to modify the grazing patterns by cattle for the restoration of sub-alpine and alpine shrub-encroached grasslands. Rangel. J. 2013, 35, 85-93.

33. Allen, V.G.; Batello, C.; Berretta, E.J.; Hodgson, J.; Kothmann, M.; Li, X.; McIvor, J.; Milne, J.; Morris, C.; Peeters, A.; et al. An international terminology for grazing lands and grazing animals. Grass Forage Sci. 2011, 66, 2-28. 
34. Cavallero, A.; Gorlier, A.; Lombardi, G.; Lonati, M.; Martinasso, B.; Tagliatori, C. I tipi pastorali delle Alpi piemontesi. Vegetazione e gestione delle Alpi occidentali; Alberto Perdisa Editore: Bologna, Italy, 2007; p. 467. (In Italian)

35. Delpech, R. Critères de jugement de la valeur agronomique des praires. Fourrage 1960, 4, 83-98. (In French)

36. Argenti, G.; Cervasio, F.; Ponzetta, M.P. Control of bracken (Pteridium aquilinum) and feeding preferences in pastures grazed by wild ungulates in an area of the Northen Appennines (Italy). Ital. J. Anim. Sci. 2012; 11, 336-341.

37. Reiné, R.; Barrantes, O.; Chocarro, C.; Juárez, A.; Broca, A.; Maestro, M.; Ferrer, C. Pyrenean meadows in natura 2000 network: Grass production and plant biodiversity conservation. Span. J. Agric. Res. 2014, 12, 61-77.

38. Cimini, D.; Tomao, A.; Mattioli, W.; Barbati, A.; Corona, P. Assessing impact of forest cover change dynamics on high nature value farmland under Mediterranean mountain landscape. Ann. Silvic. Res. 2013, 37, 29-37.

39. Ries, L.; Debinski, D.M.; Wieland, M.L. Conservation value of roadside prairie restoration to butterfly communities. Conserv. Biol. 2011, 15, 401-411.

40. Falci, A.; Livreri Console, S.; Giardina, G.; Lo Duca, R.; La Mantia, T. I Lepidotteri Ropaloceri (Insecta Lepidoptera) del bosco della Ficuzza: stato delle conoscenze e possibili relazioni tra il loro status e i cambiamenti nell'uso del suolo. Naturalista Sicil. 2012, XXXVI, 445-462. (In Italian)

(C) 2015 by the authors; licensee MDPI, Basel, Switzerland. This article is an open access article distributed under the terms and conditions of the Creative Commons Attribution license (http://creativecommons.org/licenses/by/4.0/). 